\title{
Major Salivary Gland Cancer pN2b TNM Finding V8
}

National Cancer Institute

\section{Source}

National Cancer Institute. Major Salivary Gland Cancer pN2b TNM Finding V8. NCI

Thesaurus. Code C132759.

Major salivary gland cancer with metastasis in multiple ipsilateral lymph nodes, none more than $6 \mathrm{~cm}$ in greatest dimension and ENE(-). (from AJCC 8th Ed.) 